\title{
O Thesenblatt "A missão mundial jesuíta" de 1664: exemplo da importância da religio cordis como linguagem da religião na iconografia jesuíta
}

\author{
The Thesenblatt "The Jesuit world mission" from 1664: example of the \\ importance of the religio cordis as language of religion in Jesuit iconography
}

Helmut Renders*

\begin{abstract}
Resumo
Este artigo introduz à iconografia de Thesenblätter - cartazes que anunciam as teses de disputações acadêmicas, expressão característica de disputações acadêmicas universitárias católicas dos séculos 16 e, especialmente, 17 - como um gênero próprio e importante da cultura visual europeia católica do barroco e rococó. Depois apresenta o Thesenblatt "Die Weltmission der Gesellschaft Jesu" (A Missão Mundial da Sociedade de Jesus) gravado em 1664 por Bartholomäus Kilian segundo um desenho de Johann Christoph Storer. Evidencia-se neste Thesenblatt alemão o amplo e, ao mesmo tempo, variado uso da religio cordis como linguagem imagética que caracteriza a missão mundial jesuíta, em especial, e a teologia jesuíta em geral. Através da linguagem imagética da religião do coração constrói-se a ideia de continuidade entre a teologia jesuíta, a missa de Gregório e os(as) grandes místicos(as) das épocas medieval e da reforma católica, como também estabelece uma interface com o mundo renascentista, para retomar e promover a via tripla da mística medieval como espiritualidade ideal e ortodoxa.
\end{abstract}

Palavras-chave: Jesuítas; missão jesuíta; Thesenblatt; religio cordis; iconografia.

\begin{abstract}
This article introduces to the iconography of Thesenblätter - posters advertising the theses of academic disputations, characteristic feature of an academic disputation in Catholic universities since the 16th until the 17th century - as a proper and important genre of Catholic European visual culture of the Baroque and Rococo. Next it introduces the Thesenblatt "Die Weltmission der Gesellschaft Jesu" (The World Mission of the Society of Jesus) engraved in 1664 by Bartholomäus Kilian to a design by Johann Christoph Storer. The article shows the wide and at the same time varied use of the religio cordis as imagetic language in this German Thesenblatt and points out how it characterizes the Jesuit world mission in particular and the Jesuit theology in general. The pictorial language of the religion of the heart establishes the idea of continuity between Jesuit theology, the Mass of Gregory, great mystics of medieval times and the Catholic reform and sets up an interface with the Renaissance world, to reinforce and promote the triple way of medieval mysticism as an ideal and orthodox spirituality.
\end{abstract}

Keywords: Jesuits; Jesuit mission; Thesenblatt; religio cordis; iconography.

Artigo recebido em 28 jun. 2014 e aprovado em 30 de abril de 2015

* Doutor em Ciência da Religião e Professor da Universidade Metodista de São Paulo. País de origem: Brasil. E-mail: helmut.renders@metodista.br

Horizonte, Belo Horizonte, v. 13, n. 38, p. 1021-1050, abr.jun 2015 - ISSN 2175-5841 


\section{Introdução}

Este artigo faz parte de um projeto de pesquisa maior sobre a religio cordis como expressão típica da religiosidade e da cultura visual e material religiosa brasileira, colonial e contemporânea. Quanto à época colonial, esta pesquisa é desafiada pela falta de bibliotecas jesuítas intatas em solo brasileiros - sejam elas de colégios ou de seminários.

Justifica-se, então, a procura de fontes alternativas, neste caso, de expressões europeias, por duas razões: primeiro, usavam-se no Brasil em geral livros e gravuras de origem europeia, inicialmente, da região da Antuérpia, depois da França e Espanha; segundo, pela profunda centralização e concentração do discurso jesuíta faz sentido de pressupor que discursos imagéticos de fora de Brasil não divergem em muito dos discursos dentro do país.

A pesquisa em seguida desenvolvida propõe uma ampliação da leitura da iconografia de um Thesenblatt alemão - um cartaz que anuncia as teses de uma disputação acadêmica, expressão característica da vida acadêmica universitária católica do século 16 até o século 18. Este Thesenblatt com o nome "A missão mundial jesuíta” é conhecida na pesquisa sobre o gênero dos Thesenblätter ou aiconografia jesuíta (MICHELS, 1987, p. 356-377; NOREE, 1998, p. 689-714; APPUHN-RADTKE， 2000； SCHEMMEL， 2001； CLOSSEY， 2008， p. 86; RÖMMELT, 2012), porém, nunca foi estudado em sua relação à religio cordis como uma das linguagens religiosas chave dos jesuítas.

Depois de uma breve introdução em gênero e contexto, origem e composição do respectivo Thesenblatt, segue uma análise dos seus elementos iconográficos para testar em mais um objeto da cultura jesuíta material e visual a hipótese da grande importância da linguagem da religio cordis na construção do discurso religioso jesuíta e da reforma católica. 


\section{Gênero e contexto do Thesenblatt de 1664}

O gênero dos Thesenblätter como formato visual característico pertence ao ambiente das universidades. Trata-se, tecnicamente, de cartazes que resumiram as principais teses a serem defendidas em uma disputação acadêmica, rito obrigatório para ser promovido pela universidade para o doutor. Os Thesenblätter católicos se distinguiram dos exemplares protestantes pelo amplo uso de imagens. Eles surgiram com a reforma católica, eram especialmente nos séculos 17 e 18 muito populares e desapareceram com a supressão dos jesuítas em 1773 (NOREEN, 1998, p. 689-714). Graficamente, eles pertencem à cultura do barroco e rococó. A tarefa das imagens em relação ao texto - as teses - era inicialmente, de suporte por meio de um destaque visual. Mais tarde, e aparentemente nos casos onde a formação acadêmica não foi procurada para seguir uma carreira acadêmica, mas, uma carga pública, o aspecto estético Thesenblätter poderia ser até mais importante do que as próprias teses. Em consequência a isso, era possível que exemplares muito bem elaborados - como aquele aqui em seguida discutido - foram editados ou reaproveitados até diversas vezes. ${ }^{1}$ Uma boa parte dos motivos dos Thesenblätterrepresentam ideias panegíricas ou discursos de louvor. Para isso, usam-se motivos da literatura da antiguidade, da filosofia ou dos mitos religiosos e fontes emblemáticas (cf. RÖMMELT, 2012). Dessa forma, os Thesenblätter se aproximam de outro gênero altamente prestigiado pelos Jesuítas, os livros emblemáticos. Um subtipo é o discurso panegírico dedicado ao governante, com destaque da sua tarefa de manter ou estabelecer a paz e defender a fé (SCHUMANN, 2003). Nestes casos, são em geral apresentados como inimigos do cristianismo os hereges - protestantes, eventualmente, jansenistas - e em especial os turcos (MICHELS, 1987, p. 356-377). Entretanto, como vamos ver no caso do

\footnotetext{
${ }^{1}$ Foram confirmados até agora somente exemplos da Bavária e Renânia (Alemanha), França, oeste da Suíça, e Bélgica (SCHEMMEL, 2001). A existência de exemplos italianos, espanhóis é discutida (RÖMMELT, 2012). Este resultado não favorece a existência desse costume nas universidades de Lima e de México, mas, não sabemos de nenhuma respectiva pesquisa.
} 
objeto a ser estudado, estes adversários jesuítas podem eventualmente também ser representantes da Igreja Ortodoxa.

Um Thesenblatt de uma universidade católica falando da missão mundial dos jesuítas representa um contexto e tema muito específicos. Em 1664, aproximadamente 100 anos depois da sua fundação como Ordem religiosa, os jesuítas já tinham avançados bastante em seu trabalho missionário, apologético e educacional. Quanto à percepção brasileira, estamos exatamente na metade da época hegemonia dos jesuítas no país (1549 -1749). Na Europa, jesuítas não eram somente em muitos casos os confessores de reis e rainhas, mas, assumiram também a supervisão de muitas escolas e universidades. Dessa forma aparecem Thesenblätter nas faculdades da filosofia, muitas vezes, discutindo teses da filosofia aristotélica, dentro da visão jesuíta do mundo, de Deus e da missão. Isso tinha seus aspectos tradicionais como inovadores. Apesar de que a filosofia aristotélica apresentava uma clara ideia da hierarquia entre os povos, os jesuítas articularam a salvação universal adaptada às culturas e aos costumes, línguas e modos de pensar de diversos povos (DUMOULIN, 1990, p. 256). O’ Malley (2000, p. 44) classifica Kennedy (2000, p. 322) até como "hegemonização da reconciliação de culturas" por esta Ordem. Mas, mesmo que as limitações sejam evidentes em nossa perspectiva contemporânea, não se podem negar avanços. ${ }^{2}$

\footnotetext{
${ }^{2}$ Em um estudo fascinante mostrou Bôas (2009, p. 163 e 165) o papel dos interpretes, em geral, meninos indígenas catequizadas nas escolas: "Os meninos línguas, [...] oferecem uma instância privilegiada para reavaliarmos os 'modos' que os missionários tinham de tratar com o 'gentio'. O termo 'modo', usado em geral na expressão 'nosso modo de proceder', dos jesuítas, reitera a fórmula inaciana noster modus procedendi [...] Nesse contexto emergem os hermanitos de la tierra, os irmãozinhos da terra, como personagem central da transmissão e recodificação da linguagem e dos símbolos cristãos. [...] Muito antes de José de Anchieta compor a sua gramática do tupi na década de 1560, diferentes modalidades de catecismos tupis circulavam na forma manuscrita. Ao contrário da gramática de Anchieta, feita por um inaciano professo e conhecedor do latim, esses primeiros registros da liturgia cristã contaram com a colaboração de leigos radicados na terra".
} 


\section{Figura 1: Thesenblatt “A missão mundial jesuíta”, Dillingen, Bavária, Alemanha, 1664 .}

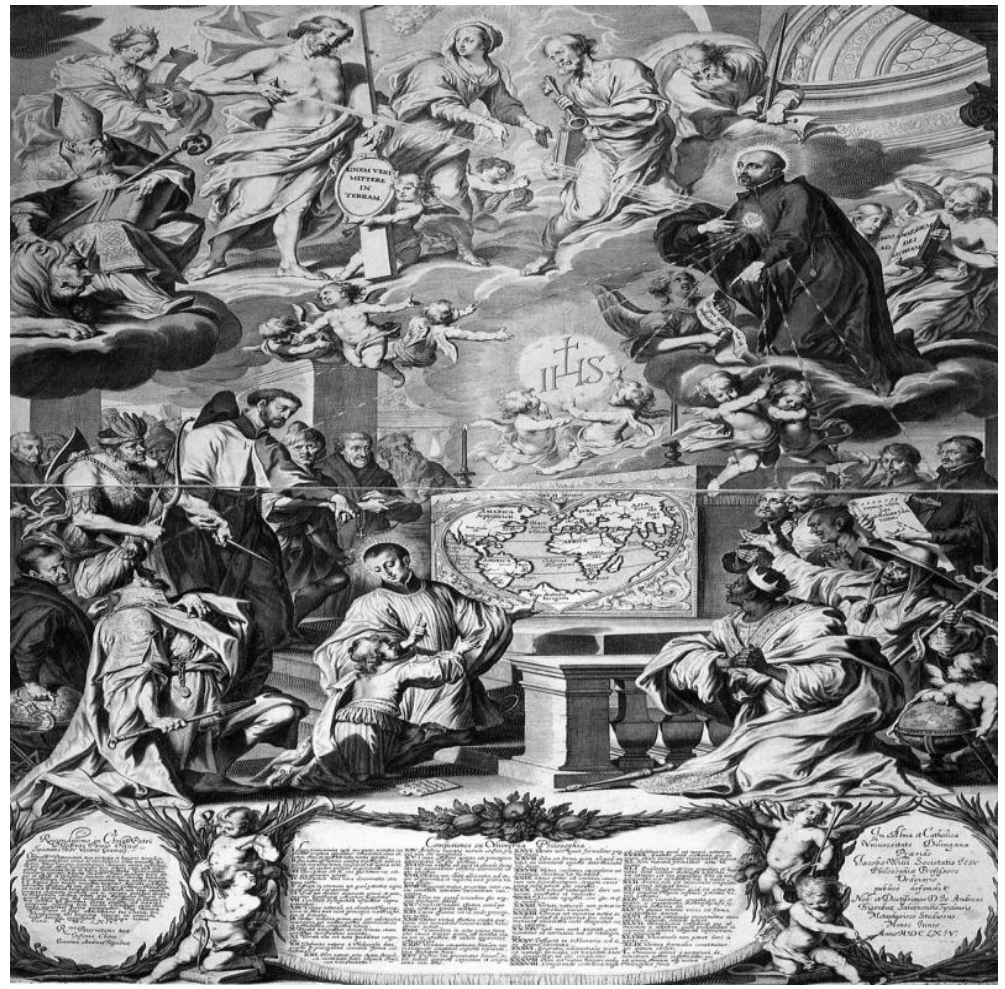

Fonte: MENZEL, 2014.

Quanto à religio cordis há um exemplo muito interessante disso que aliás transcende o mundo jesuíta. Clossey (2008, p. 247) menciona como primeira tradução de um texto chinês para uma língua europeia, no caso o espanhol, a obra Ming xin bao jing, na época transcrita como Beng Sim Po Cam, traduzido por Espejo rico del claro corazón (COBO, 1590). Este Espelho rico de um coração claro apresenta ditos de mestres de escolas confucianas, tauistas e budistas e contém 56 vezes a palavra coração que dessa forma funciona como interface entre as culturas. Para nós, a escolha de ditos ao redor da metáfora do coração corresponde à expectativa de um sistema teológico da reforma católica que favorece a linguagem da religio cordis com a theologia cordis dos jesuítas como uma das suas expressões. 


\section{Origem e composição do Thesenblatt de 1664}

O Thesenblatt com o título "Die Weltmission der Gesellschaft Jesu" (A Missão Mundial da Sociedade de Jesus) foi gravado por Bartholomäus Kilian3 (1630-1696) segundo um desenho de Johann Christoph Storer4 (1629-1671) e existe pelo menos em três edições das universidades Dillingen (1664), Friburgo (1672) e Praga (1705) (RÖMMELT, 2012)5.

Figura 2: Thesenblatt com marcação de setores

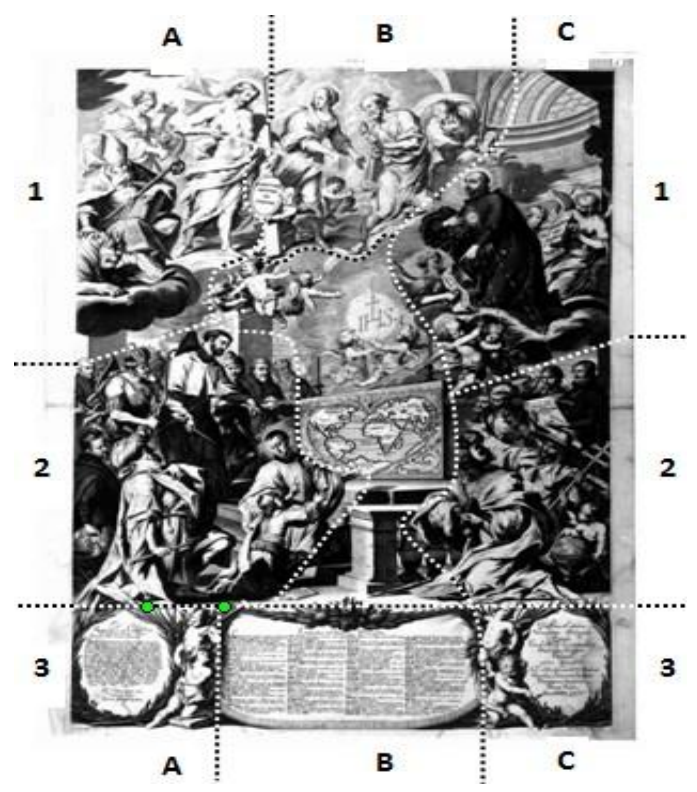

Fonte: Adaptado de Menzel, 2014.

Para facilitar propomos uma leitura da obra a partir da sua divisão em nove setores, em uma leitura ziguezague, da esquerda superior até a direita inferior, iniciando no setor A1. Entendemos que seja isso um primeiro de dois elementos chave da composição da obra. O segundo é o destaque dado aos elementos que se

\footnotetext{
${ }^{3}$ Kilian era do sul da Alemanha com base em Augsburgo, na época uma cidade grande que não se tornou protestante (PILZ, 2007, p. 603; cf. Também APPUHN-RADTKE, 1988).

${ }^{4}$ Storer foi educado em uma escola jesuíta em Constância, Alemanha, e estudou pintura em Milano. Itália. Tornou-se um artista da reforma católica com fortes vínculos com as províncias jesuítas alemães e trabalhou também para a casa real espanhola (APPUHNRADTKE, 2000).

${ }^{5}$ Parece-nos que Römmelt se baseia bastante em Clossey (2008, p. 84).
} 
encontram no centro da gravura, o trigrama cristológico da Companhia de Jesus e o altar com antependium com o mapa cordiforme.

3 Elementos do Thesenblatt de 1664 e sua relação com a religio cordis

Figura 3: Catarina de Alexandria e Inácio da Antioquia [detalhe, setor A1 do Thesenblatt: “A missão mundial jesuíta”]

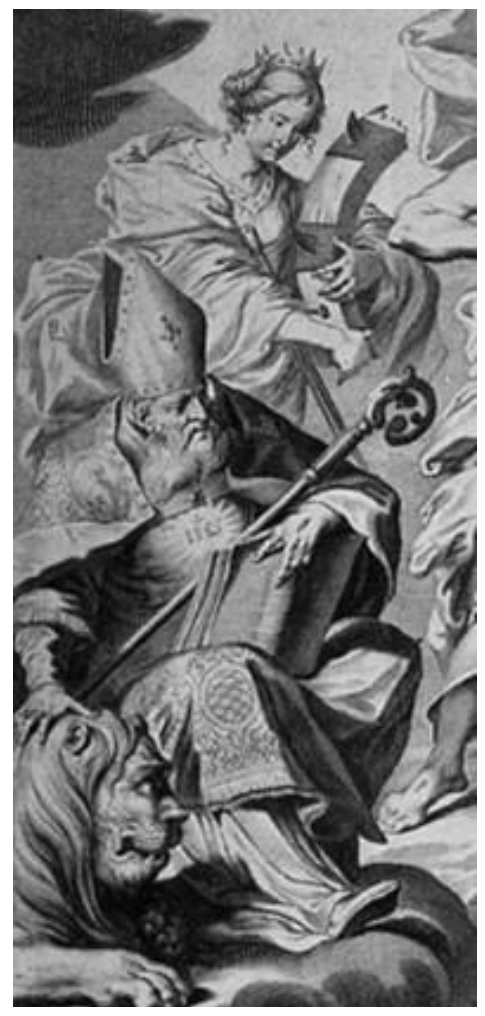

Fonte: Adaptado de Menzel, 2014.

\subsection{Grupo de santos e mártires}

Um grupo de santos fica em uma nuvem em torno de Cristo para representar várias tarefas dos jesuítas.

O primeiro destaque da gravura pertence à Catarina de Alexandria (figura 3), devidamente representada pelos seus elementos hagiográficos, a roda e a 
espada. Enquanto elas se referem às narrativas do seu martírio (a roda foi milagrosamente destruída e ela, finalmente, decapitada), está coroada pela sua perseverança na fé. A veneração de Catarina de Alexandria iniciou-se no século 10.6 Lembrada como uma mulher perspicaz e capaz de convencer pelo seu discurso adeptos de outras religiões da fé cristã, ela se tornou padroeira de estudiosos, faculdades, universidades e bibliotecas (SAUSER, 1992, col. 1213-1217). Seu aparecimento em primeiro lugar neste Thesenblatt indica também à tarefa das universidades jesuítas como promotoras da reforma católica e da contrarreforma, na luta contra a suposta heresia como tarefa essencial da Sociedade de Jesus.7

A segunda pessoa representada, Inácio Teóforo ou Inácio de Antioquia (figura 3), é mencionada na História da Igreja de Eusébio e por Origines como segundo ou terceiro bispo da cidade de Antioquia. Inácio de Antioquia foi considerado um dos Padres da Igreja e sete cartas são atribuídas a ele (LÖHR, 2009, p. 104-129). Em uma delas, a carta aos Esmirnos 8.2, introduziu o conceito “católico”. Além disso, é lembrado como defensor do episcopado monárquico como forma adequada de governo da Igreja e da necessidade de obediência aos bispos. $\mathrm{O}$ símbolo hagiográfico de Inácio de Antioquia é o leão que lembra o seu suposto martírio no Coliseu (SCHOEDEL, 1993, p. 40-45).

Inácio de Loyola conhecia a história de Inácio de Antioquia quando leu como soldado enfermo a Legenda áurea de Jacopo de Varazze (2003), escrito, originalmente, ao redor de 1260 d.C. Neste livro conta-se que o coração de Inácio de Antioquia teria recebido as letras IHS em cor dourada (APPUHN-RADTKE, 2003, p. 245). O Thesenblatt lembra este relato hagiográfico pela representação do

\footnotetext{
${ }^{6}$ Isso antecipa por dois séculos a veneração de três representantes chaves da religio cordis, Mechthild de Magdeburgo (1207/12101282/1294), Mechthild de Hackeborn (1241-1299) e Gertrude de Helfta (1256-1301).

${ }^{7}$ Segundo Appuhn-Radtke (2003, p. 255-259) os jesuítas lentamente substituíram Santa Catarina de Alexandria como patrona dos filósofos por Francisco Xavier, alegando que ele mostrou a mesma capacidade de dialogar com filósofos não cristãos em suas conversas com os chineses como a Catarina.
} 
signo IHS no seu coração. ${ }^{8}$ Além disso, como no caso da Catarina de Alexandria, registramos também a presença do signo hagiográfico do seu martírio, o leão. $\mathrm{O}$ impacto da história de Inácio de Antioquia na vida de Inácio de Loyola é conhecido: ele mudou se nome original Iñigo para Inácio em memória desse bispo mártir, defensor da obediência e modelo da reivindicação universal da Igreja Católica, agora, em tempos da contrarreforma. 9

\subsection{Grupo de personagens do Novo Testamento}

\section{Figura 4: Pedro e Paulo [Detalhe, setor B1 do Thesenblatt: “A missão mundial jesuíta"]}

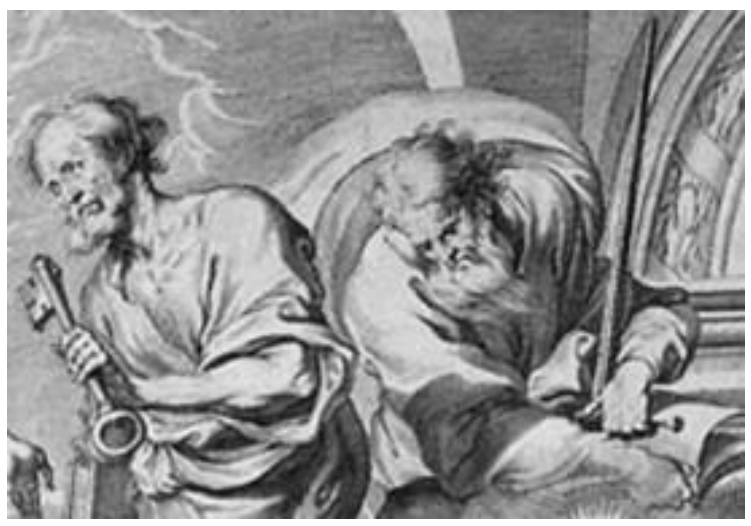

Fonte: Adaptado de Menzel, 2014 .

Pedro - com uma chave - e Paulo - com um livro e uma espada, referências ao seu apostolado entre as nações - são os dois representantes bíblicos presentes figurativamente nessa nuvem de testemunhos (figura 4). Pedro representa a base da autoridade papal - cujo escudo contém duas chaves - por ser considerado o

\footnotetext{
${ }^{8}$ Desde 1541 Ignácio de Loyola adotou as letras IHS para representar a Sociedade de Jesus. O cristograma em si é antigo a abrange um

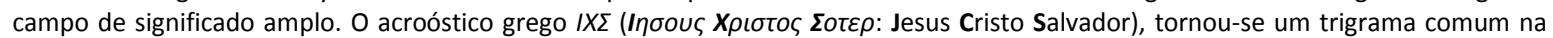
igreja do oriente e do ocidente. Ao longo tempo acresceram-se novos significados como a referência ao Cristo redentor (Iesus Hominum Salvator: Jesus salvador do ser humano) e ao Cristo rei (In hoc signo [vinces]). Quanto aos jesuítas, discute-se também lesum habemus socium (Temos Jesus como Sócio [ou amigo]) ou lesu humilis societas (A humilde sociedade de Jesus). Além de Inácio Teóforo de Antioquia, apreciava o dominicano alemão Heinrich Seuse (1300-1366), o discípulo mais importante do místico mestre Eckhardt (1260-1327), o cristograma de uma forma absolutamente singular: ele gravou o mesmo no seu peito.

${ }^{9}$ Römmelt (2012) e Clossey (2008, p. 86) apresentam Teóforo somente como "defensor da fé". Isso é pouco.
} 
início da sucessão apostólica. Paulo representa a ênfase católica na importância do magistério católico para preservar a santa doutrina (católica). Com a ênfase na defesa do papado, da santa doutrina e do magistério tanto Pedro como Paulo representam, em perspectiva jesuíta, alicerces da luta contra os hereges. Junto a Catarina de Alexandria e Inácio de Antioquia trata-se do motivo transversal e principal das figuras retratadas em maior proximidade com Jesus: o combate aos hereges, o entrelaçamento entre reforma católica e contrarreforma.

\subsection{Anjo com escudo com o lema Ignem veni mittere in terram}

Figura 5: Lema geral [Detalhe, setor B1 do Thesenblatt: “A missão mundial jesuíta"]

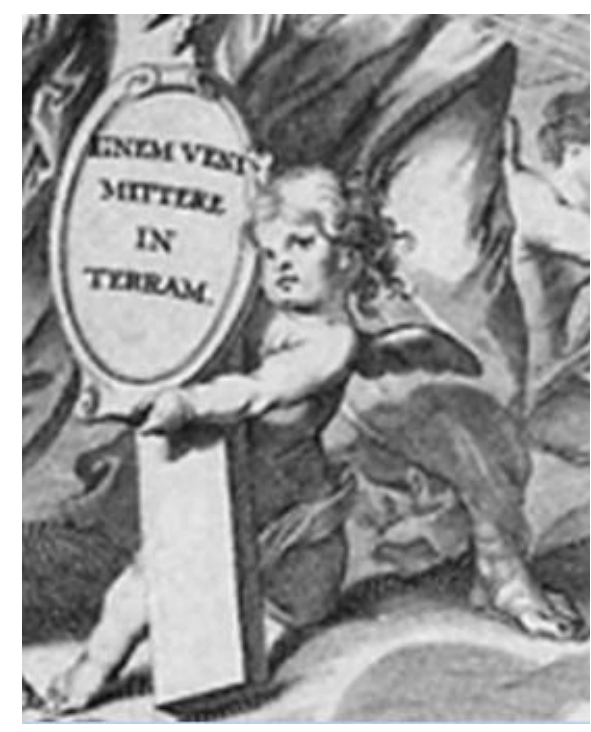

Fonte: Adaptado de Menzel, 2014.

Ainda no setor B1 encontra-se uma terceira referência bíblica e próxima indicação do pensamento de Loyola. Trata-se de um escudo, segurado por um anjo localizado na frente de Cristo, com a frase Ignem veni mittere in terram. É umacitação parcial de Lucas 12,49 - "Eu vim para lançar fogo sobre a terra [e bem quisera que já estivesse a arder]” (Lucas 12, 49) - que se tornou um lema jesuíta e que também a aparece nos Exercícios espirituais de Loyola. 
Os jesuítas se apropriam não somente da metáfora do fogo em geral para articular paixão ou ardor missionário, mas, em termos bem específicos, inclusivo no sentido original do próprio texto de Lucas: a opção da fé pode provocar conflitos até nas próprias famílias. Assim se tornou a referência a Lucas 12,49 em uma metáfora da obediência radical da Companhia de Jesus, uma obediência ao papa como ao geral da Ordem, um compromisso que ia além dos laços familiares. ${ }^{10}$

\subsection{Jesus e Loyola: a vocação missionária, a ferida lateral e o coração de Loyola}

Figura 6: Cristo, com raios de luz saindo da sua ferida lateral [Detalhe, setor A1 do Thesenblatt: “A missão mundial jesuíta”]

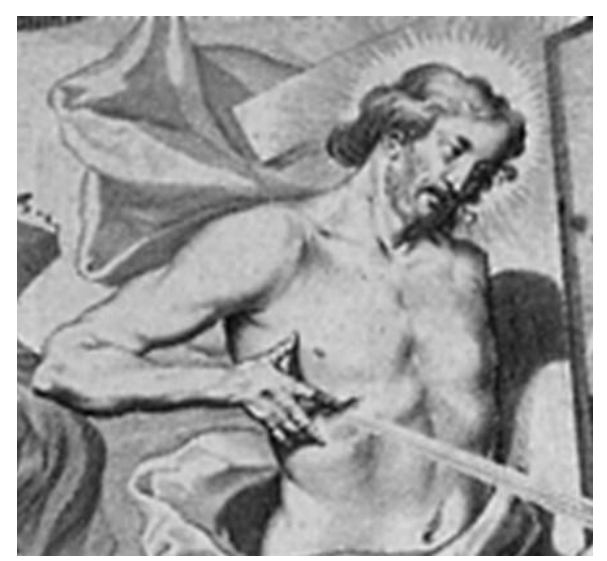

Fonte: Adaptado de Menzel, 2014.

Apesar de estar no céu (nuvens), em meio a santos e mártires, Jesus Cristo direcione seu olhar para Loyola (figura 6). Os raios de luz que saem da sua ferida lateral encontram como seu primeiro receptor o coração de Loyola (figura 7). ${ }^{11} \mathrm{O}$ olhar mútuo e os raios da luz compõem assim uma linha dupla e representam uma relação intima, contemplativa, com diversas referências a doutrinas católicas centrais e a religio cordis.

\footnotetext{
${ }^{10}$ Isso era especialmente importante nos casos de famílias ricas ou aristocratas que tinham suas próprias exigências quanto aos seus filhos.

${ }^{11}$ A mesma iconografia - raios saem do coração de Ignácio de Loyola para os quatro continentes - encontra-se na pintura a Glória do Santo Inácio (1685) de Andrea Pozzo, na Igreja de Jesus (Chies di Gesu), Roma.
} 
Figura 7: Inácio de Loyola, recebendo os raios de luz saindo da ferida lateral de Jesus em seu coração [Detalhe, setor C1 do Thesenblatt: "A missão mundial jesuíta"]

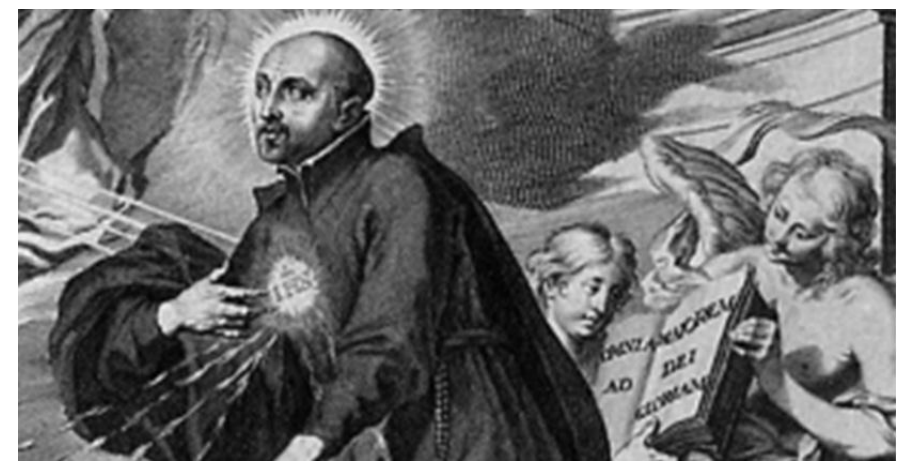

Fonte: Adaptado de Menzel, 2014 .

Figura 8: As cinco chagas de Jesus e o coração. Alemanha, 1472.

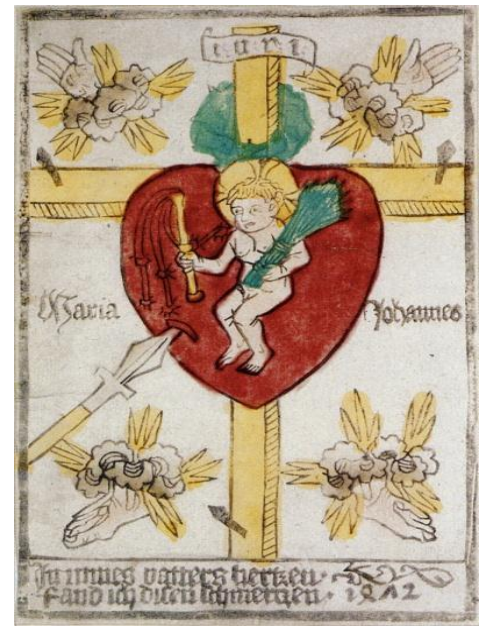

Fonte: PROMETHEUS, 2014.

A primeira relação é construída a partir da ênfase na ferida lateral de Jesus. Ela lembra da visão de Gregório o Grande (540-604 d.C.) em afirmação da doutrina da transubstanciação. No caso, sairia sangue da ferida lateral para um cálice, uma cena emblemática reproduzida, inúmeras vezes, na arte católica a partir 
do século 14. Além disso, relaciona-se a ferida lateral com a ferida do coração de Jesus, razão pela qual nas mais antigas representações do coração de Jesus ainda aparece a ferida da lança como elemento constitutivo (cf. figura 8). Assim, estabelece-se uma profunda relação entre a contemplação do sacramento como representação corporal de Jesus Cristo e repetição da sua encarnação e a contemplação do seu coração como representação do seu ser, querer, da sua kenosis mediante do amor. ${ }^{12}$

O segundo elemento da iconografia da religio cordis é o coração do próprio Loyola. É a segunda vez depois de Inácio de Antioquia (figura 3) que esta linguagem aparece. Trata-se de um fundo dourado ou brilhante com as letras IHS. $\mathrm{Na}$ iconografia jesuíta há duas formas de representar esta combinação de letras com o coração.

Figura 9: Pintura de Inácio de Loyola. Artista desconhecido

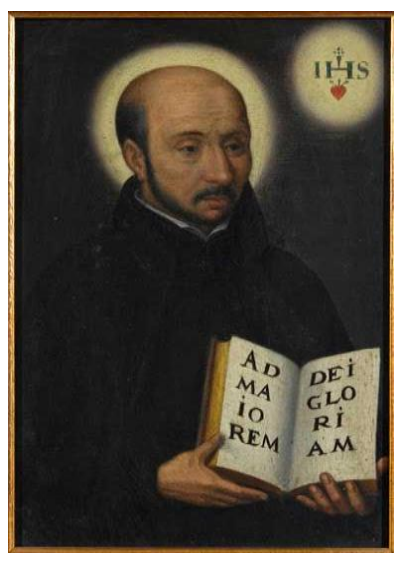

Fonte: DISCERNINGHEARTS, 2014

\footnotetext{
${ }^{12}$ Neste contexto as visões do coração de Jesus ocorrem na contemplação do Santíssimo Sacramento, como, por exemplo, no caso de Margarida Maria Alacoque (1647-1690) com quem começou a devoção ao Sagrado Coração de Jesus. Inúmeras vezes, os Santos da religio cordis são pintados, ajoelhados em frente de altares, contemplando um crucifixo e o Santíssimo Sacramento.
} 
Figura 10: Pintura de Francisco Xaver

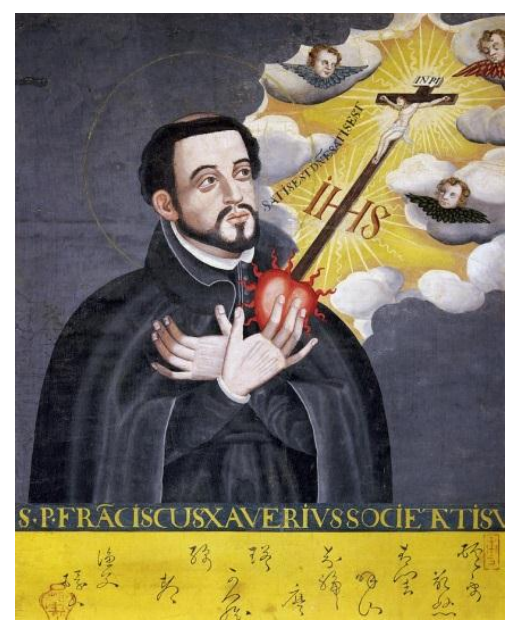

Fonte: WIKIPÉDIA, 2014.

O tipo um (figuras 8 e 9) combina um coração com as letras separadas. Inicialmente, encontram-se acima do coração três pregos (figura 8), alias, originalmente, um empréstimo da iconografia franciscana. Logo depois, aparece um coração em chamas, provavelmente, em proximidade à metáfora de Lucas 12,49 .

Figura 11: Pintura Mateus Ricci. Museu da cidade de Ingolstadt, Alemanha

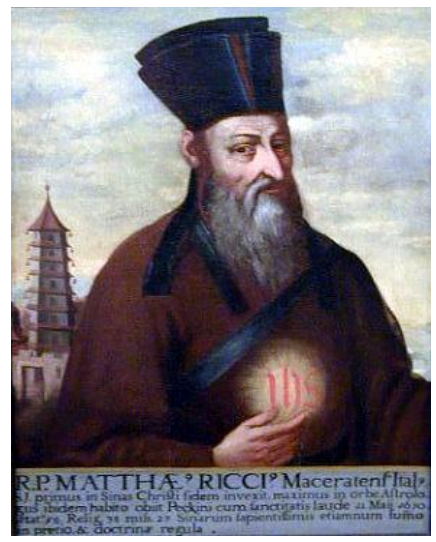

Fonte: INGOLSTADT, 2014 . 
Figura 12: Igreja de Miguel Paulista de Arcanjo. São Paulo.

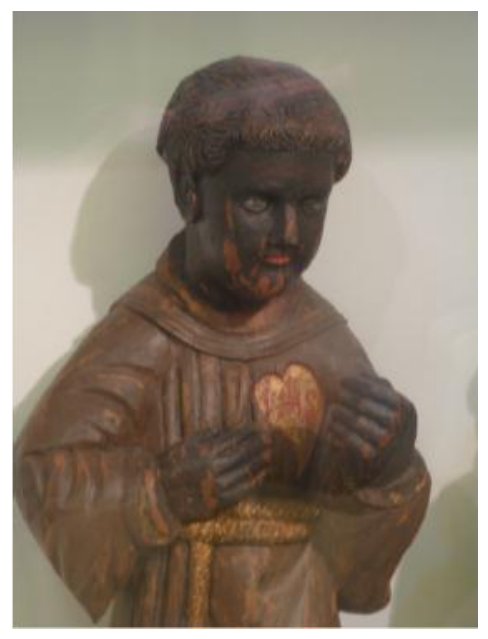

Fonte: FOTO DO AUTOR

O tipo dois pode combinar um coração com as letras IHS em seu interior (figura 11) ou as letras IHS com a base dourada (figura 10). Nos dois casos segue-se a mesma regra das cores: o fundo é dourado e as letras são escritas em vermelho.

É a iconografia comforme o segundo modelo que se encontra em nosso Thesenblatt. Na figura 7 aparece, pela primeira vez, mais um detalhe bastante que destaca as lideranças da Ordem Jesuíta: Em todo Thesenblatt reserva-se o elemento do halo ou da auréola, constitutivo em pinturas e gravuras, para articular a santidade ou designar pessoas como santas, somente para Cristo (figura 6), Maria (em setor a1), Inácio de Loyola (figura 7 ) e alguns dos missionários jesuítas ${ }^{13}$, mas, não para a Catarina de Alexandria, Inácio de Antioquia (figura 3), Pedro e Paulo (figura 4). Isso visualiza a ideia de uma proximidade qualitativa e extraordinária entre os jesuítas, Cristo e Maria, cuja veneração, mais um elemento central da reforma católica, era também promovida intensamente pelos jesuítas.

\footnotetext{
${ }^{13}$ Quanto aos jesuítas, a aplicação é consistente em mais outro sentido: a atribuição iconográfica ocorreu somente nos casos daqueles que em 1664 eram beatificados ou canonizados.
} 
Finalmente, encontramos na figura 7, próxima a pessoa de Inácio de Loyola, um livro aberto, segurado por dois anjos. O livro contém a inscrição Ad majorem Dei gloriam - Para a glória maior de Deus, lema de Loyola (cf. também figura 9)!14

\subsection{O escudo com o símbolo jesuíta e o mapa cordiforme}

\section{Figura 13: Signo IHS [Detalhe, setor B2 do Thesenblatt: “A missão mundial jesuíta"]}

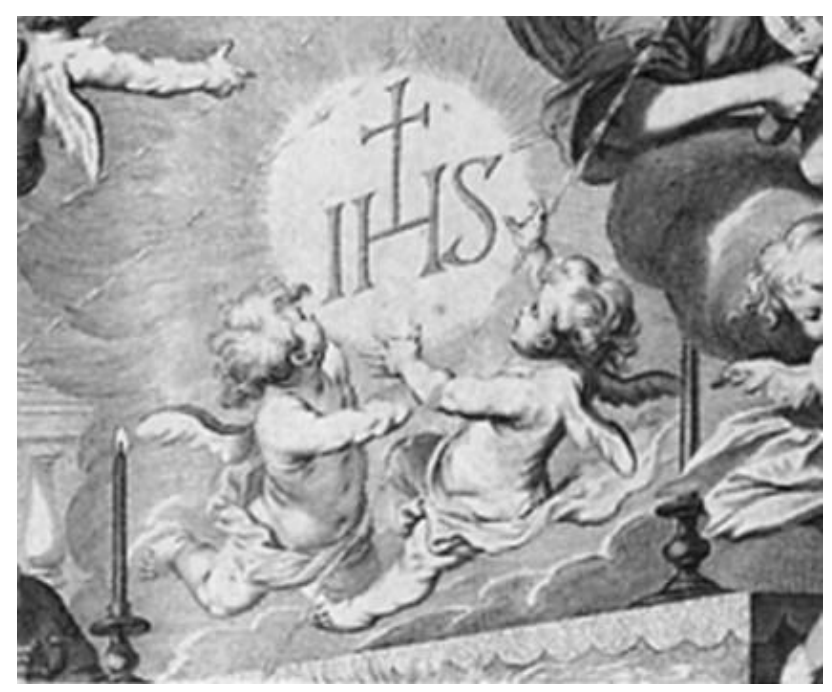

Fonte: Adaptado de Menzel, 2014.

O trigrama cristológico IHS - também iluminado por um raio saindo do coração de Loyola - aparece uma terceira vez, e neste caso, segurado por dois anjos. A localização é importante em dois sentidos: por um lado, representa junto com o mapa cordiforme, o exato centro da gravura; por outro lado, é posicionado acima de um altar - caracterizado por duas velas acesas. Nessa proximidade ao altar, o trigrama cristológico lembra até um pouco uma hóstia a ser oferecida. Assim sobrepõem-se, novamente significados. Por um lado, representa o trigrama Cristo e a eucaristia sua presença real no mundo (transubstanciação) e seu sacrifício a favor da humanidade. Por outro lado, sinaliza o trigrama cristológico

\footnotetext{
${ }^{14}$ Tanto o católico João da Cruz (1542-1591), como os músicos barrocos protestantes João Sebastião Bach (1685-1750) e Jorge Frederico Händel (1685-1759), usaram Soli Dei Gloria.
} 
neste contexto a presença da Ordem no mundo, tal como sua disposição para o martírio a favor desse mundo.

No antependium desse mesmo altar aparece um mapa do mundo em forma de coração. Ele é mais um indício da centralidade da religio cordis no discurso jesuíta. Os primeiros mapas em forma de coração (mapas cordiformes) foram criados pelo alemão Johannes Werner (1468-1522) e pelo francês Oronce Fine (1494-1550), na base dos estudos do matemático.

\section{Figura 14: Mapa cordiforme do mundo [Detalhe, setor B2 do Thesenblatt: "A missão mundial jesuíta”]}

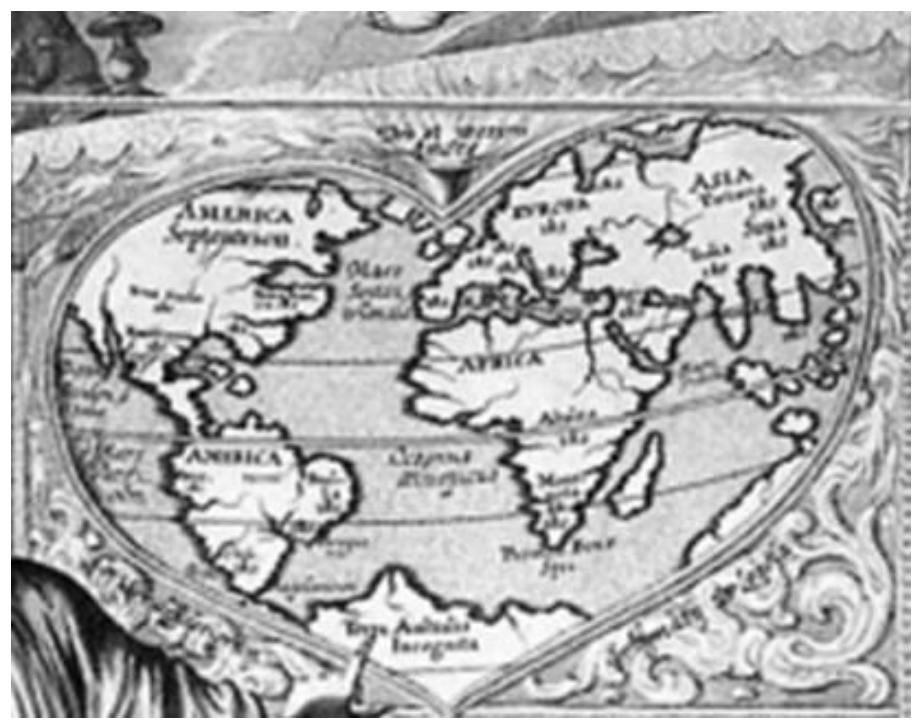

Fonte: Adaptado de Menzel, 2014 .

Johannes Strobius (1468-1522). Esta primeira projeção mais fiel do globo seguia uma lógica geográfica e não teológica (LANGLOIS, 1922, p. 83-97) e foi somente substituída pela projeção mercator, criada em 1569 e transformado em um mapa pelo cartógrafo flamengo Gerard de Kremer ou Geradus Mercator (15121594) em 1569, na base dos estudos matemáticos do inglês Edward Wright (15581615). 
O que representa, então, em 1664, a escolha de um mapa do mundo cordiforme? Os contornos dos continentes seguem claramente o modelo dos mapas antes da projeção mercator e são identificados pelos seus nomes - as Américas e a Antártica, Europa e África e a Ásia. Esta opção pode representa

- um mero costume - eram os primeiros mapas usados pelos Jesuítas;

- uma opção confessional - a projeção mercator era "protestante";

- uma crítica aos mapas com a projeção mercator - eles posicionam Europa de forma indevida, mais no centro do mundo (mais perto do equador).

Não temos como responder isso neste instante. 15 Certo é que para os jesuítas mapas mundiais eram importantes para "imaginar a missão", como Clossey (2008, p. 67-84) sugere. Ele abre o respectivo capítulo do seu livro com uma citação do teórico de arte jesuíta, Antonio Possevino, quem em 1603 afirmou:

Tenho a forte certeza que a maior arte é aquela que imita a realidade como ela é, que expressa tanto o martírio dos mártires, como as lágrimas daqueles que choram, a tristeza daqueles que sofrem, a glória e alegria no ressuscitado. Tudo isso devemos fixar em nossos corações. Esta é certamente a essência da arte (POSSEVINO apud CLOSSEY, 2008, p. 67).

Acreditamos que à "fixação no coração" como projeto, afirmado por um teórico da arte jesuíta em 1603, corresponde ao uso da religio cordis na iconografia. Clossey, porém, não segue esta pista. Depois o autor analisa o uso de mapas mundiais e, em alguns casos, seus aspectos iconográficos, chega até no Thesenblatt aqui discutido e menciona o mapa cordiforme, mas, não faz a ponte entre o imaginário da missão jesuíta e a religio cordis - apesar de que se trata de expressão essencial da mística da reforma católica jesuíta, mas, também de João da Cruz e Teresa de Ávila em continuidade de Gertrude e Mechthild de Helfta.

Voltando para o Thesenblatt, esse mapa recebeu ainda uma cosignificação por elementos iconográficos cristãos e católicos. Primeiro o mapa cordiforme

\footnotetext{
${ }^{15}$ Clossey (2008, p. 86) sugere que os mapas mundiais usados pelos jesuítas fariam simplesmente parte do imaginário da missão mundial. Acrescentaríamos: ou da sua projeção.
} 
contém, na parte superior do coração, um componente típico para a iconografia jesuíta do coração: uma abertura de qual saiam chamas. Este detalhe iconográfico aparece também nas capas de dois importantes livros emblemáticos jesuítas (figuras 15 e 16) da época:

Figura 15: Wierix, A. Cor Iesv amanti sacrvm, 1586-87 [capa].16

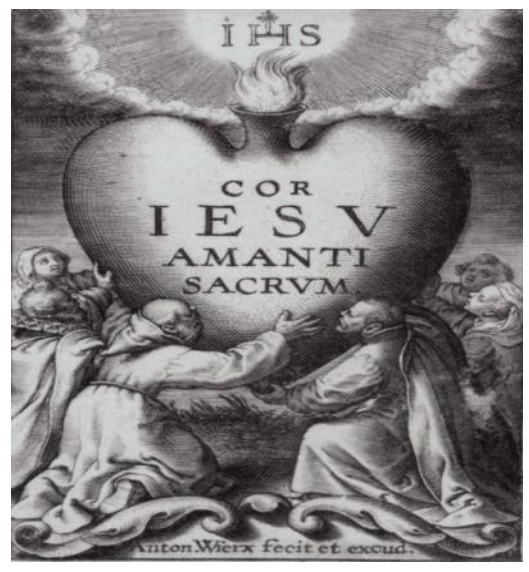

Fonte: BILDINDEX, 2014.

\section{Figura 16: Hermann, H. Pia Desideria, 1624 [capa]}

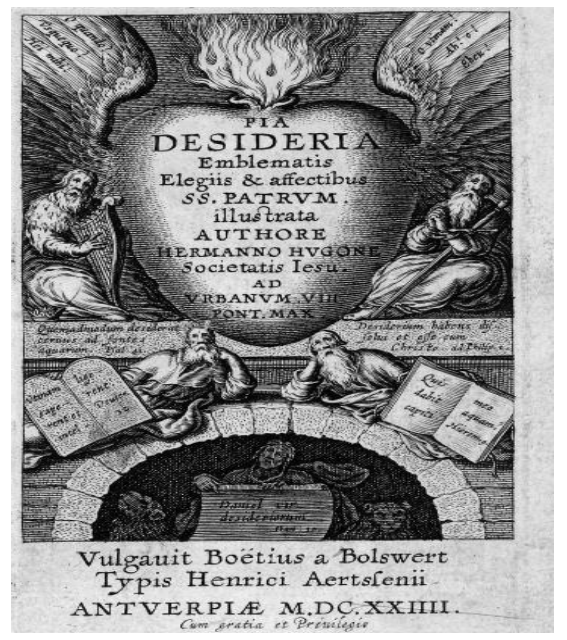

Fonte: EMBLEM PROJECT UTRECHT, 2014.

\footnotetext{
${ }^{16} \mathrm{Na}$ capa de Wierix fica Inácio de Loyola ao lado de Francisco de Assis. Appuhn-Radtke (2003, p. 244) comenta a respeito que nos séculos 15 e 16 os franciscanos de fato intensificaram bastante a veneração do nome de Jesus e do trigrama cristológico IHS.
} 
No caso do mapa cordiforme lemos, ao redor dessa abertura, Dei et proximi amor - amor para com Deus e o próximo. Na parte inferior, distribuído aos dois lados, está escrito Cor Desideriorum Viri S[ancti] Ignatii de Loyola - Os desejos do coração de um homem santo / Inácio de Loyola. Esta subscriptio lembra a Pia desideria ${ }^{17}$ - os desejos piedosos - de Hugo Hermann (1588-1629), obra publicada pela primeira vez em 1624 (figura 16), e um clássico livro emblemático do projeto catequético jesuíta, promovendo a união mística, especialmente, pelo uso dos emblemas da religio cordis. ${ }^{18}$

\subsection{Os missionários jesuítas}

Ao redor do cristograma IHS, vinculado diretamente com Loyola por raios de luz saindo do seu coração, e do mapa cordiforme, encontramos vários jesuítas: Francisco Xavier, Luís Gonzaga, André Bobola, Andrés de Oviedo e Gaspar Barzeu. Trata-se dos pioneiros de missões jesuítas na Índia, Bielorússia, Etiópia e Pérsia.

Esta escolha é um tanto eclética. Importantes representantes da primeira hora não foram reproduzidos: Alexandre Valignano, missionária na Índia (1539 1606) e Matteo Ricci (1552-1610), missionário na China ${ }^{19}$. Já Manuel da Nóbrega (1517-1570) e José de Anchieta (1534-1592), missionários jesútas pioneiros do Brasil, talvez não sejam registrados por que “... de 1502 a volta de 1650 , a joia da coroa portuguesa foi a Índia, com suas conexões com as Ilhas das Especiarias" (PEREIRA, 2014, p. 6). A ascensão em importância do Brasil - que ocorreu depois do fim da união ibérica, da perda das colônias na Ásia aos holandeses ao redor de 1648 e da descoberta de ouro e diamantes em Minas Gerais depois de 1693 - ainda não tinha deixado marcas na memória desses jesuítas alemães.

\footnotetext{
${ }^{17}$ Protestantes tendem a atribuir este titulo somente a uma obra de nome idêntico do pietista Philip Jacob Spener (1635-1705), porém a sua obra de 1675 era bem posterior à obra de Hermann.

${ }^{18}$ O livro de Herman (figura 15) faz parte de um grupo de outras obras que articulam a busca da união mística pela linguagem imagética da religio cordis. Antes de Herman publicou Antonio Wierix (1555-1604), Cor lesu amanti sacrum (1585/86), o Sagrado e amado coração de Jesus (figura 16), e logo depois, Benedictus van Haeften a sua obra Schola Cordis (1629), Escola do coração.

${ }^{19}$ Ricci era muito prestigiado em Ingolstadt, Alemanha. Esta cidade fica somente $80 \mathrm{~km}$ de Dillingen, lugar da publicação do Thesenblatt apresentado neste artigo. As instituições pertenciam a mesma província jesuíta (Bavariae societatis lesu (1556-1773).
} 
Figura 17: Francis Xaver, com índio de Goiá [Detalhe do setor A2 do Thesenblatt: "A missão mundial jesuíta”]

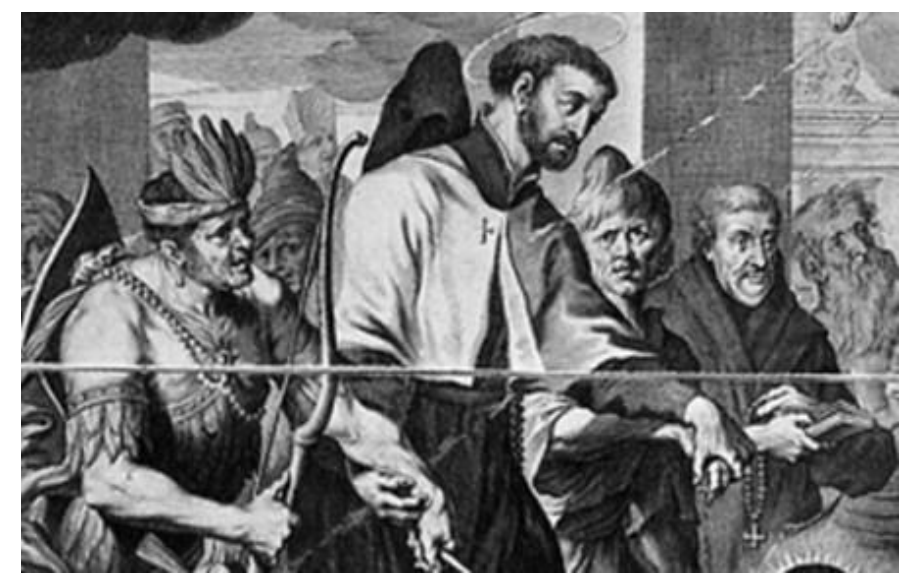

Fonte: Adaptado de Menzel, 2014.

Figura 18: Gaspar Barzaeus [Detalhe do setor A2 do Thesenblatt: "A missão mundial jesuíta"]

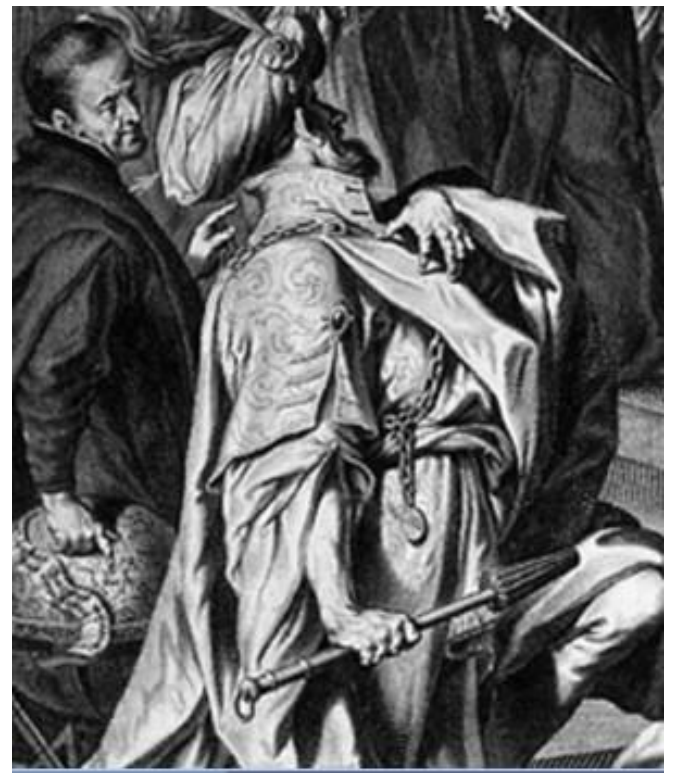

Fonte: Adaptado de Menzel, 2014 .

Francisco Xavier (1506-1552) era missionária na Índia portuguesa (Goa, Índia e Japão) e chegou também à Sri Lanka, Indonésia, mas, não à China, por 
falecer antes. A ele é atribuído a conversão de cerca de 30.0000 pessoas. A luz de Cristo, transmitido por Inácio de Loyola, chega ao coração de Francisco Xavier (figura 17). Em outra pintura jesuíta, Francisco Xavier é até retratado com um coração em chamas (figura 9). Francisco Xavier é o primeiro jesuíta depois de Inácio de Loyola que é retratado com um halo. ${ }^{20}$ Este halo se distingue das demais encontradas no Thesenblatt por um formato único: parece mais em formato de um disco do que de uma auréola. Isso representa, eventualmente, a sua importância em comparação aos demais. Mais um detalhe chama à atenção: quanto à sua missão, não há referências geográficas (globo) ou etnográficas (povos). Francisco Xavier aparece ao lado de um indígena norte-americano cujo braço ele segura. ${ }^{21}$ Jesuítas franceses estabeleceram missões duradoras na América de Norte a partir de 1634, depois de quatro tentativas fracassadas a partir de 1609. ${ }^{22}$

Na próxima cena, encontramos o holandês Gaspar Barzeu (1515-53) (figura 18). Sua mão repousa sobre um globo, indicando a sua própria área de missão, a cidade de Ormuz na Pérsia. Não tem um halo, mas, um raio chega a ele também. Em comparação ao persa que preenche em primeiro plano quase toda cena com a sua roupa opulente, Gaspar Barzeu parece retraído, mais um conselheiro do que um líder, uma pessoa mais da contemplação, segurando um rosário. De fato a missão de Gaspar Barzeu não terminou bem, em parte pelo seu trato dos judeus (SCHURHAMMER, 1973, II/3, p. 409-424). Depois da sua saída em 1568 voltaram os jesuítas somente em 1642 ao mesmo lugar.

\footnotetext{
${ }^{20}$ Isso acompanha a iconografia católica, sendo ele, junto com Loyola, canonizado como Santo já em 1622.

${ }^{21}$ Francisco Xavier segura, de fato, mais uma outra pessoa. A cena lembra de um outro conjunto iconográfico famoso: na iconografia ortodoxo segura o Cristo ressurreto com as suas mãos Adão e Eva trazendo-os junto a ela para a vida.

${ }^{22}$ As missões jesuítas espanholas na América do Norte mais antigas, na Califórnia e Arizona, iniciaram não antes de 1683, ou seja, depois da publicação desse Thesenblatt.
} 
Figura 19: Luís Gonzaga [Detalhe, setor A2 do Thesenblatt: “A missão mundial jesuíta"]

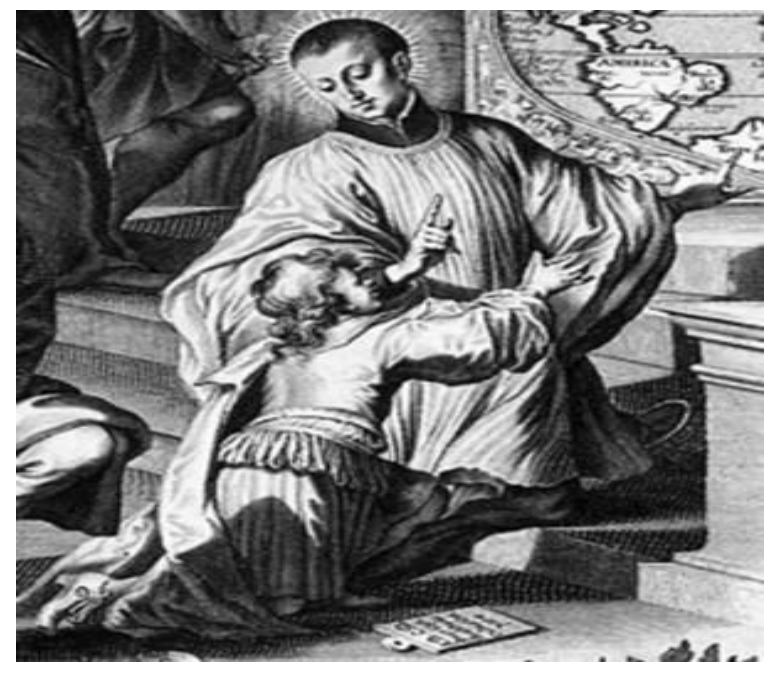

Fonte: Adaptado de Menzel, 2014.

Figura 2o: André de Oviedo [Direita abaixo, com chapéu] e André Bobola [Direita acima, com faca no peito] [Detalhe, setor C2 do Thesenblatt: "A missão mundial jesuíta"]

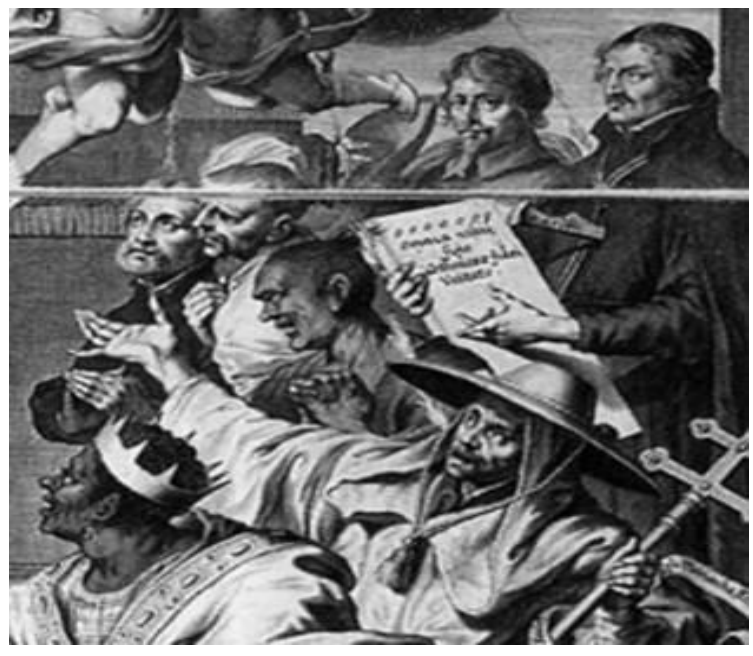

Fonte: Adaptado de Menzel, 2014. 
Luís Gonzaga (1568-1591), italiano, aparece em frente do mapa do mundo (figura 19). Gonzaga morreu jovem no tratamento de doentes em Roma. Os seus atributos hagiográficos são o lírio, em referência a sua inocência, a cruz, pela sua piedade e pelo seu sacrifico, um crânio, por causa da sua morte súbita e um rosário, pela sua veneração de Maria. Nenhum deles aparece nesta gravura. Porém, é o segundo jesuíta com um halo e o único parecido como o halo de Loyola. ${ }^{23}$ A tabula negra no chão ao lado de um jovem aluno ou estudante mostra sua primeira área de atuação. Parte dessa educação jesuíta, aparentemente, era o despertamento para a causa da missão. Muitos futuros missionários jesuítas foram instruídos em colégios jesuítas. Foi beatificado já em 1604. A sua presença neste Thesenblatt mostra sua contínua importância ainda em 1664. Posteriormente, por ocasião da sua canonização em 1726, foi declarado padroeiro da juventude e dos estudantes.

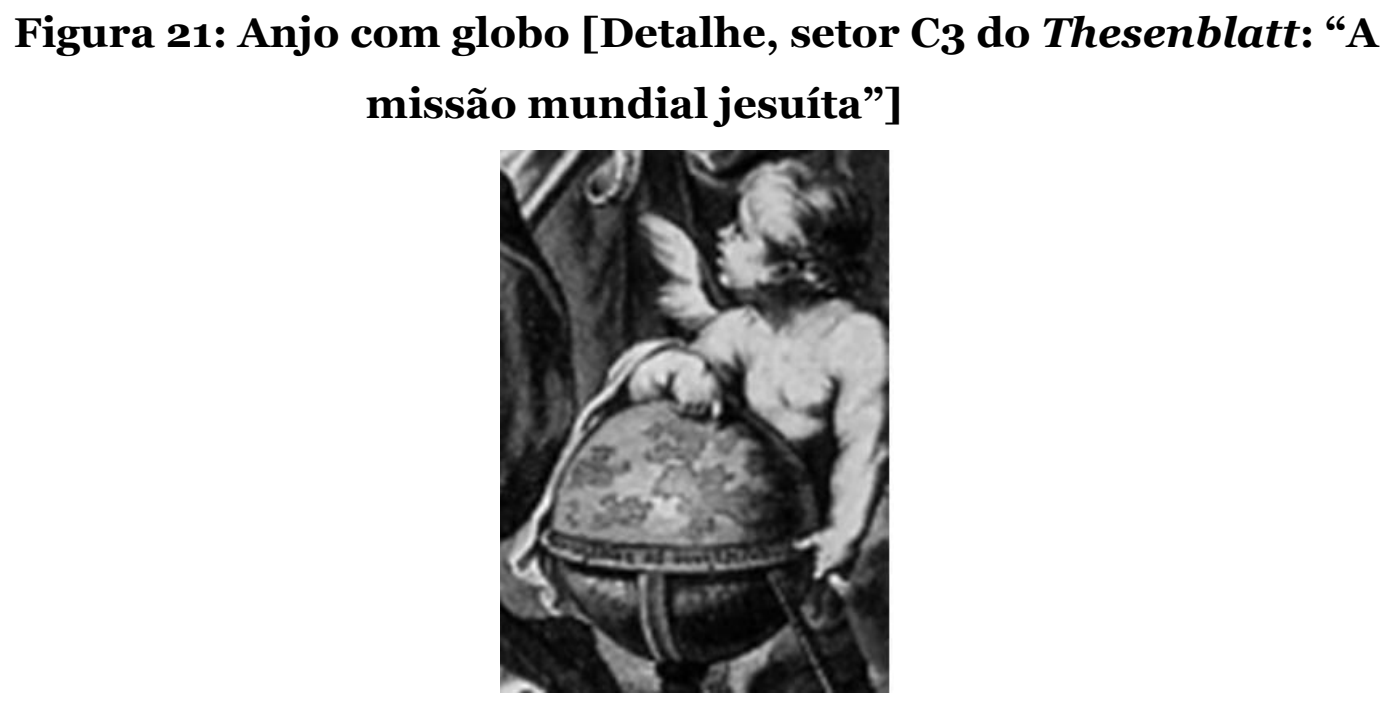

Fonte: Adaptado de Menzel, 2014 .

$\mathrm{Na}$ figura 20 são retratados três jesuítas. Conseguimos identificar o bispo jesuíta Andrés de Oviedo (1518-1577) e o jesuíta André Bobola. O lugar de atuação do espanhol Oviedo, a Etiópia, transparece pela sua maior proximidade ao rei

\footnotetext{
${ }^{23} \mathrm{Na}$ época, ele era beatificado (1605). A canonização ocorreu somente em 1726.
} 
africano. Além disso, ele pode ser identificado pelo chapéu de um bispo e a cruz dupla bizantina, na Rússia também chamada cruz de patriarca ou que o colocaria ao mesmo patamar como Patriarca de Etiópia. Provavelmente, localiza o anjo abaixo dele, apontando numa área de um globo (figura 21), identificando o lugar da sua missão, em paralelo ao caso de Gaspar Barzeu (figura 18).

O segundo jesuíta deve ser André Bobola (1591-1657). A faca no seu peito lembra o seu martírio. Ele foi assassinado por cossacos bielo-russos (cf. BAUTZ, 1990, col. 636-637), ou seja, por "heréticos ortodoxos".24 O título do livro em suas mãos não conseguimos identificar.

\section{Considerações intermediárias}

O Thesenblatt de Dillingen, criado em 1664, ou seja, em termos brasileiros, bem no meio da época da hegemonia jesuíta (1549-1759), é um tecido iconográfico complexo composto por vários fios da linguagem imagética da religio cordis católica, com citações indiretas e diretas, como elementos constitutivos da theologia cordis jesuíta. Em termos de composição e atenta à leitura de imagens que inicia normalmente na esquerda acima, o tema da religio cordis é imediatamente introduzida e da lá conectada com todos as outras partes da gravura. Além disso, reservou o artista para a religio cordis ainda o espaço central da obra.

Quanto aos agentes da religio cordis, estão no centro o próprio Jesus Cristo e, somente um pouco abaixo dele, Inácio de Loyola. Relacionado com Inácio de Loyola estão Inácio de Antioquia (como antecessor, modelo e inspiração de nome) e os missionários jesuítas (como sucessores, colaboradores), os únicos ao lado de Jesus.

\footnotetext{
${ }^{24}$ Ele não tem um halo por que foi beatificado em 1853 e canonizado somente 1938.
} 
Olhando para a gravura como um todo, a religio cordis representa o centro também no sentido de manter o mundo unido. Ao mapa cordiforme corresponde à "cordiformidade" do mundo. A religio cordis articula assim a ideia de um espaço cultural unificado com referencias ao passado e presente. A memória de Inácio de Antioquia e do papa Gregório (enquanto às representações iconográficas da sua missa) cria um vínculo com a Igreja primitiva e com a época medieval: em outras palavras, a religio cordis dá continuidade à tradição católica. Já o mapa cordiforme estabelece uma relação com a cartografia, na época das descobertas e conquistas, uma ciência de ponta: neste caso, a religio cordis corresponde ao mundo técnico contemporâneo renascentista ${ }^{25}$. Nesta gravura, a religio cordis faz parte do ideal de uma catolicidade maior, de uma universalidade que mais uma vez une tudo. Em termos espirituais, o trigrama cristológico IHS, sua relação com o altar e a referência indireta abaixo do mapa aos "desejos do coração", obra emblemática de Hugo Herman, resumem a ênfase do catolicismo tridentino na contemplação sacramental como contemplação cristocêntrica em busca da união mística. Era considerado um aspecto chave da religião ideal e antípoda à suposta proposta racionalista do protestantismo. Não devemos ignorar, porém, que o outro tipo da religio cordis, a ênfase em uma afetividade comprometida eventualmente, transparece na proposta de amar Deus e o próximo, proposta que se encontra ao redor do mesmo mapa, na sua parte superior.

Resumindo, a missão jesuíta, segundo o Thesenblatt alemão, por ocasião da defesa de uma tese acadêmica numa universidade jesuíta, é apresentada iconograficamente como motivada pela religio cordis e entendida e desenvolvida como religião "cordiforme" em proximidade daquilo que nos encontramos até agora também no Brasil. Que a missão desenvolvida no próprio Brasil não aparece nesta gravura de 1664 explica-se pelo fato que ela ainda era considerada nesta época marginal no reino Português e na percepção jesuíta, no mínimo, alemã.

\footnotetext{
${ }^{25}$ De fato, acompanharam os desenhos anatômicos realistas do coração de Leonardo da Vinci e as descobertas da circulação sanguínea as ênfases renascentistas na religio cordis.
} 


\section{REFERÊNCIAS}

APPUHN-RADTKE, Sibylle. Innovation durch Tradition. Zur Aktualisierung mittelalterlicher Bildmotive in der Ikonographie der Jesuiten. In: KARNER, Herbert ; TELESKO, Werner. Die Jesuiten in Wien: Zur Kunst- und Kulturgeschichte der österreichischen Ordensprovinz der "Gesellschaft Jesu" im 17. und 18. Jahrhundert. Wien: Verlag der Österreichischen Akademie der Wissenschaften, 2003. p. 243-260.

APPUHN-RADTKE, Sibylle. Das Thesenblatt im Hochbarock: Studien zu einer graphischen Gattung am Beispiel der Werke Bartholomaus Kilians. Weissenhorn: A. H. Konrad, 1988.

APPUHN-RADTKE, Sibylle. Visuelle Medien im Dienst der Gesellschaft Jesu: Johann Christoph Storer (1620-1671) als Maler der katholischen Reform. Regensburg: Schnell \& Steiner, 2000.

BAUTZ, Friedrich Wilhelm. Bobola, Andreas. In: Biographisch-Bibliographisches Kirchenlexi-kon (BBKL). 2 ed., Hamm: Bautz, 1990. v. 1. p. 636-637.

BILDINDEX. Wierix, A. Cor Iesv amanti sacrvm, 1586-87. 2014. < Disponível em: http://www.bildindex.de/bilder/mi11831do3c.jpg >. Acesso em: 20 jun. 2014.

BÔAS, Luciana Villas. Línguas da pregação: os meninos da terra e as missões jesuíticas no Brasil (1549-1555). Revista USP, São Paulo, n.81, p. 161-172, mar./maio 2009.

BRINKMÖLLER-GANDLAU, Harriet. Stor(r)er, Johann Christoph. In: BiografischBibliographi-sches Kirchenlexikon. Herzberg: Bautz, 1995. v. 10. p. 1587-1590.

CALAINHO, Daniela Buono. Jesuítas e medicina no Brasil colonial. Tempo, Rio de Janeiro, v. 10, n. 19, p. 61-75, jul. 2005.

CLOSSEY, Luke. Salvation and globalization in the early Jesuit Missions. New York: Cambridge University Press, 2008.

COBO, Juan. Beng Sim Po Cam: que quiere decir espejo rico del corazón, o riquezas y espejo con que se enriquezca, y donde de mire el claro y limpio corazón. [Manuscrito], [1590?]. Disponível em: < http://bdh-rd.bne.es/viewer.vm?id=ooooo5886o\&page=1 >. Acesso em: 20 jun. 2014.

DISCERNING HEARTS. Ignatius of Loyola. Artista desconhecido. Disponível em: < http://www.discerninghearts.com/blog/wp-content/uploads/2013/o7/St.-Ignatius-6.jpg >. Acesso em: 20 jun. 2014. 
DUMOULIN, H. Inkulturation in der Jesuitenmission Japans. In: SIEVERNICH, Michael; SWITEK, Gunter (Org.). Ignatianisch: Eigenart und Methode der Gesellschaft Jesu. Freiburg: Herder, 1990. p. 254-271.

EMBLEM PROJECT UTRECHT. Hermann, H. Pia Desideria, 1624. 2014. Disponível em: <http://emblems.let.uu.nl/hu1624.html>. Acesso em: 20 jun. 2014.

HERMANN, Hugo. Pia desideria emblematis. Antuérpia: Apud Henricum Aertssens, 1624 .

INGOLSTADT. Matteo Ricci. 2014. Disponível em: < http://www.ingolstadt.de/stadtmuseum/scheuerer/ausstell/bilder/sj-ricc1.jpg > . Acesso em: 20 jun. 2014.

LANGLOIS. Étude sur deux cartes d'Oronce Fine de 1531 et 1536. Journal de la Société des Américanistes, Nanterre, v. 14-15, n. 1, p. 83-97, 1922. Disponível em: < /www.persee.fr/web/revues/home/prescript/article/jsa_oo379174_1922_num_14_1_3993 >. Acesso em: 20 jun. 2014.

LECHNER, Gregor Martin. Das barocke Thesenblatt: Entstehung, Verbreitung, Wirkung: Der Göttweiger Bestand. Jahresausstellung 30. Juni bis 29. Oktober (Jahresausstellung des Graphischen Kabinetts des Stiftes Göttweig 34) Stift Göttweig. Furth: Graphisches Kabinett, 1985.

LÖHR, Hermut. Die Briefe des Ignatius von Antiochien. In: PRATSCHER, Wilhelm (Ed.). Die Apostolischen Väter: Eine Einleitung. Göttingen: Vandenhoeck \& Ruprecht, 2009. p. 104-129.

LONDOÑO, Fernando. Escrevendo cartas: jesuítas, escrita e missão no século XVI. Revista Brasileira de História, São Paulo, v. 22, n. 43, p. 11-32, jan./jun. 2002.

LUCAS. In: A Bíblia Sagrada: Antigo e Novo testamento. Tradução João Ferreira de Almeida, edição revisada e atualizada. Rio de Janeiro: Sociedade Bíblica do Brasil, 1988.

KENNEDY, T. Frank. Candide and a boat. In: O'MALLEY, John W. et al (Ed). The jesuits: cultures, sciences, and the arts, 1540-1773. 2nd ed. Toronto: University of Toronto Press, 2000. p. 317-335.

MENZEL, Ulrich. 1664: Die Weltmission der Jesuiten. 2014. Disponível em: < http://www.ulrich-menzel.de/odw/Jesuitenmission_gross.jpg>. Acesso em: 20 jun. 2014

MICHELS, Anette. Philosophie und Herrscherlob als Bild: Anfänge und Entwicklung des süddeutschen Thesenblattes im Werk des Augsburger Kupferstechers Wolfgang Kilian (1581-1663). In: Kunstgeschichte, Form und Interesse. Münster: Lit, 1987. v. 10. p. $356-377$.

NOREEN, Kirstin. Ecclesiae militantis triumphi: Jesuit iconography and the CounterReformation. Sixteenth Century Journal, Kirksville, v. 29, n.3, p. 689-714, 1998. 
O'MALLEY, John W. et al (Ed). The jesuits: cultures, sciences, and the arts, 1540-1773. 2nd ed. Toronto: University of Toronto Press, 2000.

PEREIRA, Clifford. East in the west: investigating the Asian presence and influence in Brazil from the sixteenth to the eighteenth centuries. In: TILBURG, Hans Van et al (Org.). Proceedings of the $2^{\text {nd }}$ Asia-Pacific Regional Conference on Underwater Cultural Heritage. Honolulu: Asia-Pacific Regional Conference on Underwater Cultural Heritage Planning Committee, 2014. Disponível em: < https://www.academia.edu/ 7444400/East_in_the_West_Investigating_the_Asian_presence_and_ influence_in_Brazil_from_the_sixteenth_to_the_eighteenth_centuries $>$. Acesso em: 22 jun. 2014.

PILZ, Kurt. Kilian, Bartholomäus II. Neue deutsche biographie, 1977. v. 11. p. 603. Disponível em: < http://www.deutsche-biographie.de/pnd11885500X.html >. Acesso em: 20 jun. 2014.

PROMETHEUS. Fünf Wundmale, Heiliges Hery mit Christusknabe, 1472. 2014. Disponível em: < http://prometheus.unikoeln.de/images/imago/r400x400/oooob6bo.jpg?_asd=00554251805c692956d2dc6d5c 2f521338099dc98a915eo72d >. Acesso em: 20 jun. 2014.

RÖMMELT, Stefan W. Thesenblatt. Aus: Medien und Kommunikation. 2012. Disponível em: < http://www.historicum.net/no_cache/persistent/artikel/2645/ >. Acesso em: 19 jun.2014.

SAUSER, Ekkart. Katharina von Alexandria. In: Biographisch-Bibliographisches Kirchenlexi-kon (BBKL). Herzberg: Bautz, 1992. (Col. 1213-1217; v. 3).

SCHEMMEL, Bernhard. Die graphischen Thesen- und Promotionsblätter in Bamberg: Bestandskatalog der Staatsbibliothek Bamberg, des Historischen Vereins Bamberg in der Staatsbibliothek Bamberg, des Erzbischöflichen Priesterseminars Bamberg, des Historischen Museums der Stadt Bamberg und auswärtiger Sammlungen sowie von Privatbesitz. Wiesbaden: Harrassowitz, 2001.

SCHOEDEL, William R. Ignatius von Antiochien. In: Theologische Realenzyklopädie. Göttingen: Walter de Gruyter, 1993. v. 16. p. 40-45.

SCHUMANN, Jutta. Das barocke Thesenblatt. In: Die andere Sonne: Kaiserbild und Medienstrategien im Zeitalter Leopolds I. Berlin: Akademie Verlag, 2003.

SCHURHAMMER, Georg. Franz Xaver: sein Leben und seine Zeit. Freiburg: Herder, 1963-1973. v. 3 .

VAN HAEFTEN, Benedictus. Schola cordis. Antuérpia: [s.n.], 1627.

VARAZZE, Jacopo. Legenda áurea: vida dos santos. Tradução Hilário Franco Júnior. Rio de Janeiro: Companhia das Letras, 2003. 
WIERIX, Antonio. Cor Iesv amanti sacrvm. Antuérpia: [s.n.], 1585-86.

WIKIPÉDIA. Francisco Xavier: retrato japonês do período Nanban. 2014. Disponível em: <

http://pt.wikipedia.org/wiki/Francisco_Xavier\#/media/File:Franciscus_de_Xabier.jpg >. Acesso em: 20 jun. 2014. 